\title{
NEW DEVELOPMENTS IN THE TREATMENT OF ALCOHOL USE DISORDER
}

\author{
MARIA BONEA *, IOANA VALENTINA MICLUȚIA \\ "Iuliu Hațieganu" University of Medicine and Pharmacy, Department of Neuroscience, Psychiatry, 43 Victor Babeș Street, \\ 400012, Cluj-Napoca, Romania
}

*corresponding author: Bonea.Maria@umfcluj.ro

Manuscript received: February 2018

\begin{abstract}
Alcohol dependence is a chronic disorder with frequent relapses. Even the most motivated individuals have difficulties in maintaining abstinence, and require pharmacotherapy, apart from psychotherapy. Current anti-craving medications (acamprosate, naltrexone, nalmefene, disulfiram) have only limited efficacy. The present paper aims to review both the agents developed within the last 10 years (novel opioid and vasopressin antagonist, dopamine, cannabinoid, glucocorticoid and orexin receptors modulators) and the drugs already prescribed for other uses (anticonvulsants, muscle relaxants, antihypertensives, antiemetics, and even neuroimmune modulators and antiparasitic drugs), which were proven beneficial for controlling heavy drinking.
\end{abstract}

\section{Rezumat}

Dependența alcoolică este o patologie cronică, recăderile fiind frecvente. Chiar și indivizii motivați mențin cu dificultate abstinența, necesitând psihoterapie, dar și terapie medicamentoasă. Medicația anti-craving actuală (acamprosat, naltrexonă, nalmefen, disulfiram) are eficacitate limitată. Prezentul articol își propune o trecere în revistă a compușilor descoperiți în ultimii 10 ani (noi antagonişti opioizi şi de vasopresină, modulatori ai sistemelor dopaminergic, canabinoid, corticoid şi orexinic), dar şi a medicamentelor utilizate deja în practica clinică cu alte indicaţii (anticonvulsivante, antiparazitare, miorelaxante, antihipertensive, antiemetice şi chiar modulatoare neuroimune), care s-au dovedit utile în controlul consumului de alcool.

Keywords: dependence, alcohol, anti-craving agents

\section{Introduction}

Addiction, a chronically relapsing condition, involves significant perturbations of the most important neurotransmitter pathways [22]. The fifth edition of the Diagnostic and Statistical Manual of Mental Disorders (DSM-5) reunites alcohol abuse and dependence in a single entity, Alcohol use disorder (AUD), adding craving as a diagnostic criterion. Thus, an individual receives this diagnosis if, in a 12 month period meets 2 out of the 11 criteria: inability to stop drinking, failed attempts to abstain, long periods of intoxication or recovery after heavy drinking, social, professional and family difficulties, declining pleasant activities in order to imbibe, involvement in risky behaviour while intoxicated, continuing drinking despite negative physical and psychiatric consequences, increasing the consumed amounts to obtain the same effects (tolerance), developing withdrawal and an intense desire to drink (craving) [2]. The variation between AUD symptom combinations generates numerous different phenotypes, which require targeted treatment and could explain the contradictory results of the clinical trials [24]. The main cerebral molecular targets of alcohol are the pentameric ligand-gated ion-channels (pLGIC), N-methyl-D-aspartate (NMDA) receptors, L-type $\mathrm{Ca}^{2+}$ ion channels and $\mathrm{G}$ protein-activated inwardly rectifying $\mathrm{K}^{+}$channels (GIRKSs). The pLGIC receptors include the inhibitory glycine receptor (GlyR), $\gamma$-aminobutyric acid type $\mathrm{A}\left(\mathrm{GABA}_{\mathrm{A}}\right)$ and the excitatory nicotinic acetylcholine receptor (nAChR) and 5-hydroxytryptamine3 (5-HT3), on which alcohol has an agonist effect [42].

The approved drugs for AUD therapy are disulfiram, naltrexone, nalmefene and acamprosate. The first approved agent was disulfiram, an irreversible inhibitor of aldehyde dehydrogenase which generates a potentially dangerous aversive reaction, limiting its use only to healthy individuals, a requirement difficult to meet in AUD patients. Also, disulfiram decreases craving by inhibiting dopamine-beta-hydroxylase which leads to elevated levels of dopamine [3].

At the ventral tegmental area (VTA), a part of the mesolimbic reward circuit, alcohol stimulates the $\mu$ opioid receptors located on dopaminergic neurons both directly and indirectly, through elevated levels of endogenous opioids. Consecutively, the opioid neurons increase dopamine release in the nucleus accumbens, generating euphoria [44].

Koob and Volkow describe the three stages of dependence, with the correspondent neural circuits: the binge/intoxication stage stimulated by the basal nuclei and maintained through positive feedback due 
to pleasure (reward seeking), the withdrawal/negative affect stage controlled by the amygdala (seeking relief) and the preoccupation/anticipation stage (craving) with the activation of the prefrontal cortex [22]. The progression of the disorder implies the predominance of one of the 3 pathways. Based on this theory, the recently published PREDICT study proved a better response to naltrexone, a $\mu$ and k-opioid receptor antagonist, for the "relief drinkers" subgroup, with a significant decrease of heavy drinking (more than 5 drinks per day for man and more than 4 drinks per day for women; a "standard drink" or "unit" varies between 8 to 23.5 grams of alcohol, depending on the country) [18]. The hypothesis of the same clinical trial that acamprosate would be more effective on the "relief drinking" subgroup wasn't confirmed [29]. Ethanol potentiates GABA induced inhibition and reduces glutamate stimulation. During withdrawal, excessive glutamate becomes neurotoxic, especially since GABA is insufficient. These events are countered by acamprosate, a taurine derivate which acts like "artificial alcohol" by inhibiting the glutamate system (blocking the metabotropic glutamate receptors, mGluR), thus indirectly inhibiting the GABAergic system [12]. The latest approved treatment (only in Europe) for AUD is the $\mu, \delta$ and k-opioid antagonist nalmefene.
With the advantage of an "as needed" administration, some studies declare it superior to naltrexone [43]. The present article briefly reviews the latest attempts to discover safer and more effective therapeutic alternatives for AUD, focusing on major neurotransmitter systems (Table I).

\section{Materials and Methods}

We searched papers published between 2008 and 2017 in PubMed, Medline, SpringerLink and Elsevier databases. The search terms were therapy/treatment, alcohol dependence/alcoholism. Both preclinical and clinical studies were included.

\section{Results and Discussion}

The GABAergic system. Gabapentin, an antiepileptic which modulates GABA transmission by interacting with voltage-gated calcium channels (VGCCs), reduces craving, dysphoria and insomnia and is useful both for the treatment of mild withdrawal and, in the long term, for relapse prevention [28, 31]. A GABA derivate, $\gamma$-hydroxybutyric acid or sodium oxybate (GHB) was proven effective both for alcohol withdrawal and for maintaining abstinence and is already approved for AUD in Italy and Austria [17].

Table I

A summarized outlook of the new agents for AUD and the neurotransmitter systems involved in their action

\begin{tabular}{|c|c|c|}
\hline Neurotransmitter system & Agent & Current use \\
\hline \multirow{4}{*}{$\gamma$-aminobutyric acid (GABA) } & gabapentine & anticonvulsant \\
\hline & $\gamma$-hydroxybutyric acid or sodium oxybate (GHB) & alcohol withdrawal, "date rape drug" \\
\hline & avermectines & antiparasitic \\
\hline & baclofen & muscle relaxant \\
\hline \multirow{4}{*}{ Glutamate } & topiramate & \multirow{2}{*}{ anticonvulsant } \\
\hline & zonisamide & \\
\hline & D-cycloserine & tuberculosis \\
\hline & Guanfacine & ADHD \\
\hline \multirow{2}{*}{ Opioid } & LY2196044 & \multirow{3}{*}{ new } \\
\hline & GSK1521498 & \\
\hline Dopamine & OSU6162 & \\
\hline Acetylcholine & varenicline & smoking cessation \\
\hline Norepinephrine & $\begin{array}{l}\text { prazosin } \\
\text { doxazosin }\end{array}$ & $\begin{array}{c}\text { hypertension, benign prostatic } \\
\text { hyperplasia }\end{array}$ \\
\hline \multirow{3}{*}{ Serotonin } & odansetron & antiemetic \\
\hline & D-Lysergic acid diethylamide (LSD) & \multirow{2}{*}{ hallucinogenic } \\
\hline & psilocybin & \\
\hline \multirow{2}{*}{ Glucocorticoid } & CP376395 & \multirow{2}{*}{ new } \\
\hline & CRF6-33 & \\
\hline \multirow[t]{2}{*}{ Cannabinoid } & rimonabant & $\begin{array}{l}\text { smoking cessation, obesity } \\
\text { (preclinical) }\end{array}$ \\
\hline & AM4113 & \multirow{3}{*}{ new } \\
\hline Vasopressin & ABT-436 & \\
\hline Orexin & SB-334867 & \\
\hline
\end{tabular}

Nevertheless, the potential for abuse and misuse (a so called "date rape drug") makes it risky especially for patients with psychiatric comorbidities [6]. The antiparasitic drugs avermectines limit ethanol ingestion in mice by stimulating $\mathrm{GABA}_{\mathrm{A}}$ receptors and by blocking the effects of alcohol on purinoceptor 4 (P2X4R). This class of receptors, ion channels activated by adenosine triphosphate (ATP), could 
FARMACIA, 2019, Vol. 67, 2

become a target for the development of new treatments for AUD [10]. Baclofen, a $\mathrm{GABA}_{\mathrm{B}}$ agonist approved for muscle spasticity, decreases alcohol consumption (ethanol is a presynaptic $\mathrm{GABA}_{\mathrm{B}}$ antagonist), but only on low ( $<90 \mathrm{mg}$ /day) or high doses (>150 mg/day) and is already frequently prescribed off-label for AUD in European countries like France [34, 38].

The glutamate system. The glutamate antagonists and anticonvusants topiramate and zonisamide have moderate effect for the treatment of AUD, but their cognitive side effects are a major reason for noncompliance [21]. D-cycloserine, an antituberculosis medication, was shown to diminish craving by acting as a glutamatergic NMDA partial agonist at the gycine site [20]. Guanfacine, a $\alpha 2$ adrenenoreceptor agonist approved for the treatment of Attention Deficit Hyperactivity Disorder (ADHD) can modulate the glutamatergic neurotransmission in the medial prefrontal cortex (mPFC), thus reducing alcohol intake in rats, but clinical trials are in order to validate this effect in humans [11].

The opioid system. New compounds such as LY2196044, a $\mu, \delta$ and k-opioid antagonist and GSK1521498, a $\mu$-opioid antagonist were shown useful for abstinence maintaining, the latter was even more effective than naltrexone in decreasing alcohol consumption in mice [36, 47].

The dopaminergic system. A new monoamine stabilizer that modulates dopamine levels in the nucleus accumbens, OSU6162 diminished craving and the pleasure related to alcohol consumption in highly impulsive individuals in a phase II human laboratory study [19].

The cholinergic system. The prevalence of tobacco use disorder among individuals with AUD is approximately double than in the general population, with half the persons with heavy alcohol use being smokers [46]. Varenicline, prescribed for smoking cessation, is a nicotinic partial agonist, selective for the $\alpha 4 \beta 2 \mathrm{sub}-$ type present on dopaminergic neurons from the VTA. It was shown to decreases drinking both in smokers and non-smokers alcoholics [7, 37].

The adrenergic system. In animal models, prazosin and doxazosin, $\alpha 1$-adrenoreceptor antagonists usually prescribed for hypertension and benign prostatic hyperplasia, prevented stress induced alcohol consumption [13]. Furthermore, the combined blockade $\alpha-1$ and 5$\mathrm{HT}_{2}$ by adding cyproheptadine could reverse alcohol preference [45]. Although promising, these effects have yet to be validated in humans.

The serotoninergic system. The antiemetic ondansetron, a selective 5-HT3 antagonist, combined with topiramate, decreases the relapse rate [32]. D-Lysergic acid diethylamide (LSD) is a partial $5-\mathrm{HT}_{2 \mathrm{~A}}$ agonist, a $5-\mathrm{HT}_{1 \mathrm{~A}}$ agonist in the Dorsal Raphe and a D2 agonist in the VTA, at high doses, might trigger psychotic-like effects [9]. A meta-analysis of six clinical trials concluded that a single dose of LSD was an effective augmentation to several AUD therapy programs [25]. Comparable long term results were obtained with psilocybin, another hallucinogenic very similar structurally to 5-HT [5]. The glucocorticoid system. Corticotropin-releasing factor (CRF) is considered to control the anxiety/stresslike effects of withdrawal and abstinence, the so called "dark side" of dependence [22]. Type 1CRF-receptor antagonists (such as CP376395) infused into the VTA of mice, decreased stress-escalated alcohol intake [15]. Type 2 CRF-receptor antagonists (astressin-2B) and CRF binding protein (CRFBP) antagonist CRF fragment 6-33 (CRF6-33) combined reduced binge-like drinking in a similar experiment [1]. While the preclinical studies were encouraging, currently, the results were not translated to humans.

The cannabinoid system. The two types of presynaptic cannabinoid receptors on GABA and glutamate neurons could be another target for ethanol binding, promoting sedation $[8,40]$. Rimonabant is a cannabinoid receptor 1 (CB1) inverse agonist, was proven beneficial for smoking cessation, obesity and also for controlling drinking in preclinical studies. Nevertheless, clinical studies on heavy alcohol drinkers showed no effect in humans [14]. On the other hand, AM4113, a CB1 antagonist diminishes binge-like drinking behaviour in mice, without any apparent adverse effects [4]. Other mechanisms. A recent vasopressin type $1 \mathrm{~b}$ (V1b) receptor antagonist, ABT-436 increased the number of days of abstinence, especially in high stress alcoholics in a phase 2, double-blind, placebo-controlled randomized trial [39]. Another similar study determined that the supplement benfotiamine, a S-acyl synthetic derivate of thiamine, diminished alcohol intake notably in women [30]. Animal studies showed the role of SB-334867, a type 1 orexin receptors antagonist present in the nucleus accumbens and the mPFC, in the control of compulsive alcohol consumption [26, 27]. In a randomized, placebo-controlled, human laboratory trial, ibudilast, a neuroimmune modulator, reduced cue-induced craving, particularly in alcoholics with comorbid depression [35]. One of the epigenetic mechanisms involved in the development of addiction is histone deacetylation with chromatin remodelling. The counteraction of this phenomenon by new agents, such as MS-275 and sodium butyrate reduced the impulse to drink, the amounts of ethanol ingested and relapses $[16,41]$. This model suggests that intermittent exposure to alcohol during adolescence could induce long term histone alterations in the amygdala which could lead to anxiety and AUD [32].

\section{Conclusions}

The literature contains extensive research on new agents for the treatment of AUD, involving most of the neurotransmitter systems (GABA, glutamate, serotonin, dopamine, cannabinoid, orexin or vasopressin). Each 
mechanism could be more effective for certain groups of patients, according to their phenotype.

\section{References}

1. Albrechet-Souza L, Hwa LS, Han X, Zhang EY, DeBold JF, Miczek KA, Corticotropin Releasing Factor Binding Protein and CRF2 Receptors in the ventral tegmental area: modulation of ethanol binge drinking in C57BL/6J mice. Alcohol Clin Exp Res., 2015; 39(9): 1609-1618.

2. American Psychiatric Association. Diagnostic and Statistical Manual of Mental Disorders ( $5^{\text {th }}$ Ed.). Arlington, VA: American Psychiatric Publishing, 2013; 490-491.

3. Antonelli M Ferrulli A, Sestito L, Vassallo GA, Tarli C, Mosoni C, Rando MM, Mirijello A, Gasbarrini A, Addolorato G, Alcohol addiction - the safety of available approved treatment options. Exp Opin Drug Saf., 2018; 17(2): 169-177.

4. Balla A, Dong B, Shilpa BM, Vemuri K, Pandey SC, Sershen H, Suckow RF, Vinod KY, Cannabinoid-1 receptor neutral antagonist reduces binge-like alcohol consumption and alcohol-induced accumbal dopaminergic signaling. Neuropharmacology, 2018; 131: 200-208.

5. Bogenschutz MP, Forcehimes AA, Pommy JA, Wilcox CE, Barbosa PC, Strassman RJ, Psilocybinassisted treatment for alcohol dependence: a proofof-concept study. J Psychopharmacol., 2015; 29(3): 289-299.

6. Caputo F, Del Re A, Brambilla R, Grignaschi A, Vignoli T, Vigna-Taglianti F, Addolorato G, Zoli G, Cibin M, Bernardi M. Sodium oxybate in maintaining alcohol abstinence in alcoholic patients according to Lesch typologies: a pilot study. J Psychopharmacol.. 2014; 28(1): 23-30.

7. Chirila M, Ghita I, Fulga I, Current knowledge on bupropion and varenicline clinical efficacy in nicotine dependence. Farmacia, 2015; 63(1): 1-7.

8. Cong L, Jiao Y, Dong Y, The effect of lamotrigine monotherapy after conversion from the combined therapy lamotrigine and valproic acid in patients with epilepsy. Farmacia, 2017; 65(6): 885-890.

9. De Gregorio D, Comai S, Posa L, Gobbi G, dLysergic Acid Diethylamide (LSD) as a model of psychosis: mechanism of action and pharmacology. Int J Mol Sci., 2016; 17(11): 1-20.

10. Franklin KM, Asatryan L, Jakowec MW, Trudell JR, Bell RL, Davies DL, P2X4 receptors (P2X4Rs) represent a novel target for the development of drugs to prevent and/or treat alcohol use disorders. Front Neurosci., 2014; 8: 176: 1-12.

11. Fredriksson I, Jayaram-Lindstrom N, Wirf M, Nylander E, Nystrom E, Jardemark K, Steensland P, Evaluation of guanfacine as a potential medication for alcohol use disorder in long-term drinking rats: behavioral and electrophysiological findings. Neuropsychopharmac., 2015; 40(5): 1130-1140.

12. Frye MA, Hinton DJ, Karpyak VM, Biernacka JM, Choi DS, Port JD, Anterior cingulate glutamate is reduced by acamprosate treatment in patients with alcohol dependence. J Clin Psychopharmacol., 2016; 36(6): 669-674.
13. Funk D, Coen K, Tamadon S, Li Z, Loughlin A, Le AD, Effects of prazosin and doxazosin on yohimbineinduced reinstatement of alcohol seeking in rats. Psychopharmacology (Berl.), 2016; 233(11): 21972207.

14. George DT, Herion DW, Jones CL, Phillips MJ, Hersh J, Hill D, Heilig M, Ramchandani VA, Geyer C, Spero DE, Singley ED, O'Malley SS, Bishai R, Rawlings RR, Kunos G. Rimonabant (SR141716) has no effect on alcohol self-administration or endocrine measures in nontreatment-seeking heavy alcohol drinkers. Psychopharmacology (Berl.), 2010; 208(1): 37-44.

15. Hwa LS, Holly EN, DeBold JF, Miczek KA, Social stress-escalated intermittent alcohol drinking: modulation by CRF-R1 in the ventral tegmental area and accumbal dopamine in mice. Psychopharmacology (Berl.), 2016; 233(4): 681-690.

16. Jeanblanc J, Lemoine $\mathrm{S}$, Jeanblanc $\mathrm{V}$, Alaux-Cantin S, Naassila M, The Class I-Specific HDAC inhibitor MS-275 decreases motivation to consume alcohol and relapse in heavy drinking rats. Int $J$ Neuropsychopharmacol., 2015; 18(9): 1-9.

17. Keating GM, Sodium oxybate: a review of its use in alcohol withdrawal syndrome and in the maintenance of abstinence in alcohol dependence. Clin Drug Investig., 2014; 34(1): 63-80.

18. Kerr WC, Stockwell T, Understanding standard drinks and drinking guidelines. Drug Alcohol Rev., 2012; 31(2): 200-205.

19. Khemiri L, Steensland P, Guterstam J, Beck O, Carlsson A, Franck J, Jayaram-Lindstrom N, The effects of the monoamine stabilizer (-)-OSU6162 on craving in alcohol dependent individuals: A human laboratory study. Eur Neuropsychopharmacol., 2015; 25(12): 2240-2251.

20. Kiefer F, Kirsch M, Bach P, Hoffmann S, Reinhard I, Jorde A, von der Goltz, Spanagel R, Mann K, Loeber S, Vollstadt-Klein S, Effects of D-cycloserine on extinction of mesolimbic cue reactivity in alcoholism: a randomized placebo-controlled trial. Psychopharmacol (Berl.), 2015; 232(13): 2353-2362.

21. Knapp CM, Ciraulo DA, Sarid-Segal O, Richardson MA, Devine E, Streeter CC, Oscar-Berman M, Surprise C, Colaneri L, Putnam M, Waters M, Richambault C, Zonisamide, topiramate, and levetiracetam: efficacy and neuropsychological effects in alcohol use disorders. J Clin Psychopharmacology., 2015; 35(1): 34-42.

22. Koob GF, Volkow ND, Neurobiology of addiction: a neurocircuitry analysis. Lancet Psychiatry, 2016; 3(8): 760-773.

23. Koob GF, The role of CRF and CRF-related peptides in the dark side of addiction. Brain Res., 2010; 1314: 3-14.

24. Kranzler HR, McKay JR, Personalized treatment of alcohol dependence. Curr Psychiatry Rep., 2012; 14(5): 486-493.

25. Krebs TS, Johansen PO, Lysergic acid diethylamide (LSD) for alcoholism: meta-analysis of randomized controlled trials. J Psychopharmacol., 2012; 26(7): 994-1002.

26. Lei K, Wegner SA, Yu JH, Hopf FW, Orexin-1 receptor blockade suppresses compulsive-like alcohol drinking 
in mice. Neuropharmacology, 2016; 110(Pt A): 431-437.

27. Lei K, Wegner SA, Yu JH, Mototake A, Hu B, Hopf FW, Nucleus Accumbens Shell and mPFC but not insula Orexin-1 receptors promote excessive alcohol drinking. Front Neurosci., 2016; 10: 400: 1-14.

28. Leung JG, Hall-Flavin D, Nelson S, Schmidt KA, The role of gabapentin in the management of alcohol withdrawal and dependence. Ann Pharmacother., 2015; 49(8): 897-906.

29. Mann K, Roos CR, Hoffmann S, Nakovics H, Heinz A, Witkiewitz $\mathrm{K}$, Precision medicine in alcohol dependence: A controlled trial testing pharmacotherapy response among reward and relief drinking phenotypes. Neuropsychopharmacology, 2018; 43(4): 891-899.

30. Manzardo AM, He J, Poje A, Penick EC, Campbell J, Butler MG, Double-blind, randomized placebo-controlled clinical trial of benfotiamine for severe alcohol dependence. Drug Alcohol Depend., 2013; 133(2): 562-567.

31. Mason BJ, Quello S, Goodell V, Shadan F, Kyle M, Gabapentin treatment for alcohol dependence: a randomized clinical trial. JAMA Intern Med., 2014; 174(1): 70-77.

32. Pandey SC, Sakharkar AJ, Tang L, Zhang H, Potential role of adolescent alcohol exposure-induced amygdaloid histone modifications in anxiety and alcohol intake during adulthood. Neurobiol Dis., 2015; 82: 607-619.

33. Paparrigopoulos T, Tzavellas E, Karaiskos D, Kourlaba G, Liappas I, Treatment of alcohol dependence with low-dose topiramate: an open-label controlled study. BMC Psychiatry, 2011; 11: 41: 1-7.

34. Pignon B, Labreuche J, Auffret M, Gautier S, Deheul S, Simioni N, Cottencin O, Bordet R, Duhamel A, Rolland B, The dose-effect relationship of baclofen in alcohol dependence: A 1-year cohort study. Hum Psychopharmacol., 2017; 32(5): 1-6.

35. Ray LA, Bujarski S, Shoptaw S, Roche DJ, Miotto K, Development of the neuroimmune modulator Ibudilast for the treatment of alcoholism: A randomized, placebocontrolled, human laboratory trial. Neuropsychopharmacology, 2017; 42(9): 1776-1788.

36. Ripley TL, Sanchez-Roige S, Bullmore ET, Mugnaini M, Maltby K, Miller SR, Wille DR, Nathan P, Stephens DN, The novel mu-opioid antagonist, GSK1521498, reduces ethanol consumption in C57BL/6J mice. Psychopharmacology (Berl.), 2015; 232(18): 3431-3441.

37. Roberts W, Harrison ELR, McKee SA, Effects of varenicline on alcohol cue reactivity in heavy drinkers. Psychopharmacology (Berl.), 2017; 234(18): 27372745.

38. Rolland B, Auffret M, Labreuche J, Lapeyre-Mestre M, Dib M, Kemkem A, Grit I, Drelon M, Duhamel A,
Cabe N, Vabret F, Guillin O, Baguet A, Masquelier C, Dervaux A, Deheul S, Bordet R, Carton L, Jardri R, Gautier S, Phone-based safety monitoring of the first year of baclofen treatment for alcohol use disorder: the BACLOPHONE cohort study protocol. Exp Opin Drug Saf., 2017; 16(2): 125-132.

39. Ryan ML, Falk DE, Fertig JB, Rendenbach-Mueller B, Katz DA, Tracy KA, Strain EC, Dunn KE, Ciraulo DA, Sickles-Colaneri L, Ait-Daoud N, Johnson BA, Ransom J, Scott C, Koob GF, A phase 2, doubleblind, placebo-controlled randomized trial assessing the efficacy of ABT-436, a novel V1b receptor antagonist, for alcohol dependence. Neuropsychopharmacology, 2017; 42(5): 1012-1023.

40. Segarceanu A, Ghita I, Sova AC, Radu MC, Fulga I, Antinociceptive properties of diethylamine in rodents: Role of the cannabinoid and opioid receptors. Farmacia, 2014; 63(3): 589-600.

41. Simon-O'Brien E, Alaux-Cantin S, Warnault V, Buttolo $\mathrm{R}$, Naassila M, Vilpoux C, The histone deacetylase inhibitor sodium butyrate decreases excessive ethanol intake in dependent animals. Addict Biol., 2015; 20(4): 676-689.

42. Soderpalm B, Lido HH, Ericson M, The Glycine receptor-A functionally important primary brain target of ethanol. Alcohol Clin Exp Res., 2017; 41(11): 1816-1830.

43. Soyka M, Friede M, Schnitker J, Comparing Nalmefene and Naltrexone in alcohol dependence: Are there any differences? Results from an indirect meta-analysis. Pharmacopsychiatry, 2016; 49(2): 66-75.

44. Stahl SM, Stahl's Essential Psychopharmacology. Neuroscientific Basis and Practical Applications, $4^{\text {th }}$ Edition. Cambridge University Press, New York, 2013; 551-559.

45. Trovero F, David S, Bernard P, Puech A, Bizot JC, Tassin JP, The Combination of marketed antagonists of $\alpha 1 b$-adrenergic and 5-HT2A receptors inhibits behavioral sensitization and preference to alcohol in mice: A promising approach for the treatment of alcohol dependence. PloS One, 2016; 11(3): e0151242: $1-10$.

46. Weinberger AH, Gbedemah M, Goodwin RD, Cigarette smoking quit rates among adults with and without alcohol use disorders and heavy alcohol use, 20022015: A representative sample of the United States population. Drug Alcohol Depend., 2017; 180: 204-207.

47. Wong CJ, Witcher J, Mallinckrodt C, Dean RA, Anton RF, Chen Y, Fijal BA, Quyang H, Dharia S, Schuh KJ, Kinon BJ, A phase 2, placebo-controlled study of the opioid receptor antagonist LY2196044 for the treatment of alcohol dependence. Alcohol Clin Exp Res., 2014; 38(2): 511-520. 